\title{
REVIEW
}

\section{NEW INSIGHTS ON THE DIAGNOSIS AND MANAGEMENT OF MALIGNANT TUMORS OF THE OCULAR SURFACE}

\author{
F. Mallone, A. V. Chicca, P. Sagnelli, M. Sacchetti, A. Lambiase \\ ${ }^{1}$ Department of Sense Organs, Sapienza University of Rome, Policlinico Umberto I, Rome, Italy
}

\section{CORRESPONDING AUTHOR:}

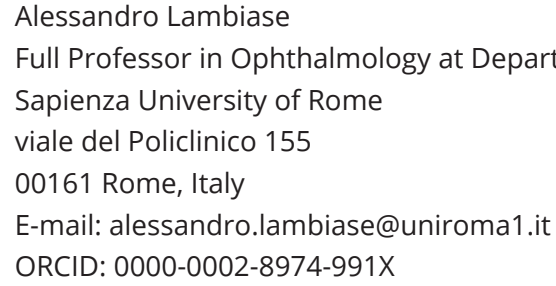

\section{ABSTRACT}

Tumors of the ocular surface encompass a wide spectrum of conditions involving the conjunctiva and cornea, ranging from benign lesions to life-threatening malignancies. These tumors are rare; however, they are commonly seen in the ophthalmological clinical practice as a group.

The diagnosis of ocular surface tumors is mostly based on clinical evaluation of the conjunctiva and cornea and subsequent histologic confirmation. Recently, non-invasive diagnostic approaches including anterior segment high-resolution OCT (HROCT), showed promising results for their use as adjuvant for histology in case of suspicious lesions.
The present review focused on the main malignant ocular surface tumors, including ocular surface squamous neoplasia (OSSN), melanocytic epithelial tumors, and conjunctival lymphoma, with the aim of discussing the epidemiological, clinical, and histopathological features, as well as to provide insights into classification and staging. In addition, the latest advances in the treatment of ocular surface tumors were reviewed, including the use of topical chemotherapy, which is gaining increasing acceptance over surgical tumor removal as it prevents surgery-related side effects and tumor recurrences.

\section{KEY-WORDS}

Ocular surface squamous neoplasia (OSSN); conjunctival melanoma; conjunctival lymphoma; anterior segment high-resolution OCT (HR-OCT); topical chemotherapy.

\section{IMPACT STATEMENT}

This review is aimed at providing clinical description of the main malignant ocular surface tumors along with recent advances in the diagnosis and treatment of these conditions. 


\section{INTRODUCTION}

Tumors of the ocular surface encompass a broad spectrum of conditions involving the conjunctiva and cornea, and are classified based on site of origin into epithelial, stromal, caruncular, metastatic and secondary tumors (table I). Tumors of the ocular surface range from benign lesions such as conjunctival nevus, dermoid or squamous papilloma, to aggressive, life-threatening malignancies such as squamous cell carcinoma (SCC), lymphoma or melanoma (figures 1-3).

The conjunctiva is a mucous membrane which covers the back surface of the eyelid, the fornixes, and the anterior surface of the globe up to the corneo-scleral limbus. The conjunctiva is composed of a multilayered, non-keratinized epithelium and a stroma. Melanocytes are normally located in the basal layer of the conjunctival epithelium. The cornea is a clear, avascular structure that is composed of stratified, non-keratinized squamous epithelium, a stroma and a corneal endothelium. Melanocytes are described in the basal epithelial layer of the peripheral cornea, but they are absent in the central cornea. The corneo-scleral limbus represents the junction of the corneal and conjunctival epithelia. It contains the palisades of Vogt in which are located corneal stem cells. This region is also a common site for the development of corneal epithelial tumors (1). Ocular surface neoplasms arise from both epithelial and stromal structures; however, corneal stromal tu-

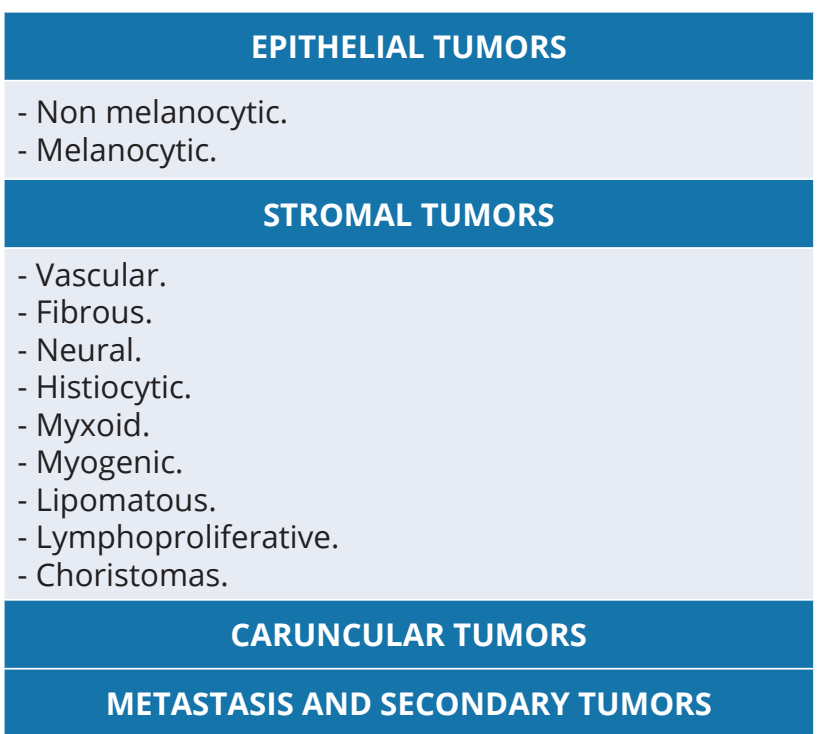

Table I. Classification of tumors of the ocular surface. Modified from Grossniklaus et al. (4), Shields et al. (5) and Honavar et al. (6). mors are uncommon. Epithelial tumors of the ocular surface can be further subdivided in non-melanocytic or melanocytic (table II). The cornea is frequently invaded by tumors originating in the conjunctiva.

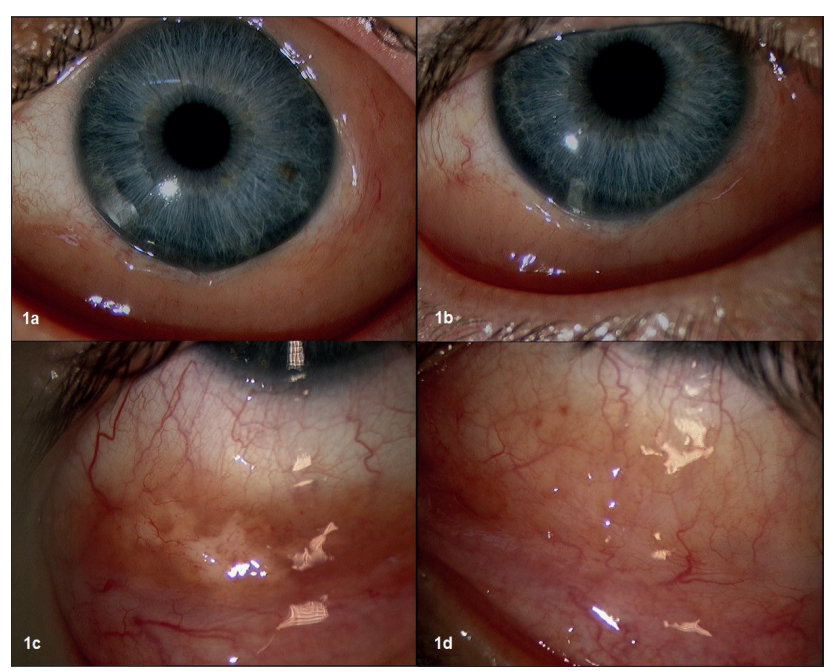

Figure 1. $\boldsymbol{a}, \boldsymbol{c}$. Bilateral conjunctival lymphoma, right eye. $\boldsymbol{b}$, $\boldsymbol{d}$. Left eye. $\boldsymbol{a}, \boldsymbol{b}$. Diffuse, slightly elevated, salmon-colored mass in the bulbar conjunctiva. Clinical appearance before. $\boldsymbol{d}, \boldsymbol{c}$. After systemic treatment.
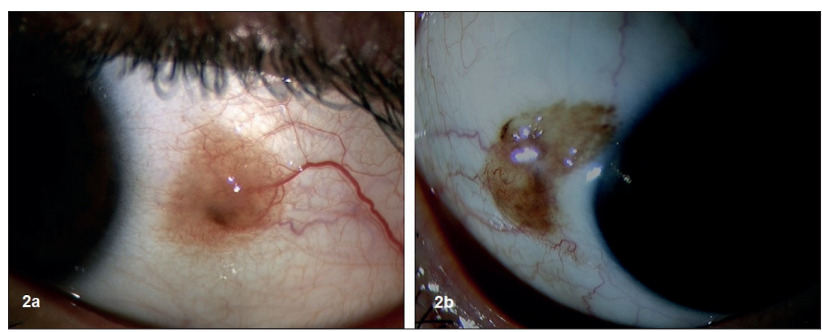

Figure 2. $\boldsymbol{a}, \boldsymbol{b}$. Clinical aspect of two different conjunctival nevi showing intralesional cysts and feeder vessels.

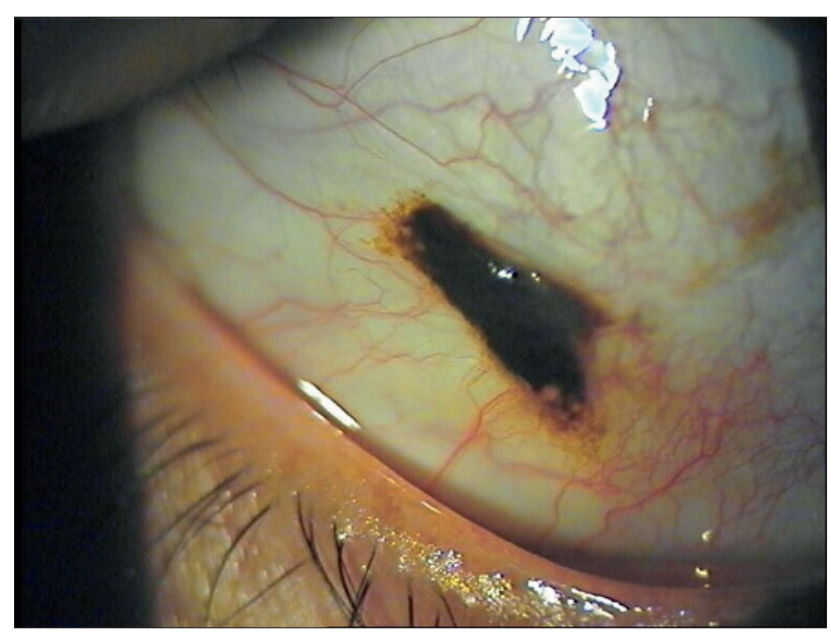

Figure 3. Conjunctival melanoma. Pigmented, elevated, non-cystic mass with feeding and intrinsic vessels in the interpalpebral bulbar conjunctiva. 


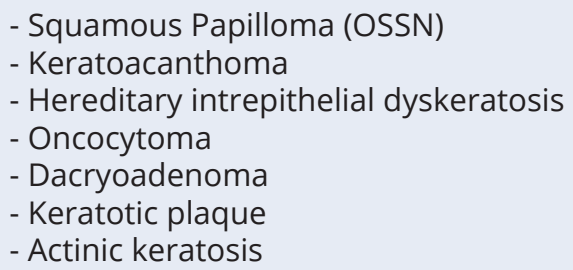

\section{BENIGN MELANOCYTIC EPITHELIAL TUMORS} EPITHELIAL TUMORS

- Conjunctival Nevus

- Complexion-associated melanosis (CAM)

- Primary Acquired Melanosis (PAM)

\section{MALIGNANT MELANOCYTIC}

Table II. Classification of epithelial tumors of the ocular surface.

Modified from Grossniklaus et al. (4), Shields et al. (5) and Honavar et al. (6).

Corneal involvement is characterized by loss of transparency and potential impairment of visual function. Conjunctiva and cornea allow for direct clinical evaluation, therefore, ocular surface tumors may be easily diagnosed, however, differentiating between benign and malignant ocular surface lesions, as well as among different malignant conditions, can be challenging for ophthalmologists and oncologists. Indeed, with the exception of tumor size, clinical features such as tumor location, keratinization, pigmentation, vascularization, and corneal invasion have not been associated with the likelihood of malignancy (1). Based on these observations, additional diagnostic exams and histopathologic confirmation after incisional or excisional biopsy are mandatory in the presence of suspected lesions. It is worth to note that an accurate and early diagnosis is critical, due to differences in the treatment and prognosis of these conditions.

\section{Ocular surface squamous neoplasia}

Ocular surface squamous neoplasia (OSSN) is the most common epithelial, non-melanocytic malignancy of the ocular surface. It involves neoplastic changes of the squamous epithelium of the cornea and conjunctiva, progressing from dysplasia to conjunctival intraepithelial neoplasia (CIN) (Tis: carcinoma in situ) and invasive SCC.

Risk factors include ultraviolet (UV) light exposure, fair skin, infection with human papillomavirus (HPV), human immunodeficiency virus (HIV), prior skin cancer, older age (2-8).

OSSN lesions generally present as unilateral disease, but may be bilateral in immunosuppressed patients. They are thought to arise from the limbal stem cells, and most commonly occur in the interpalpebral region involving the bulbar conjunctiva and/or the cornea (9). They can be flat or raised, localized or diffuse, and may have surface keratin and feeder conjunctival vessels. They usually present as fleshy, placoid lesions with a gelatinous, leukoplakic, velvety or papilliform appearance, and may coexist with other ocular surface disorders. Nodular and diffuse morphological types are less common $(10,11)$. Of note, a diffuse appearance can simulate chronic conjunctivitis (12). When present at the cornea, they present as a flat opalescent layer $(10,11)$.

Histopathologic examination shows an invasive disease, characterized by malignant squamous cells crossing the basement membrane and growing in sheets or cords into the stromal tissue. Aggressive variants include spindle cell squamous carcinoma, mucoepidermoid carcinoma, and adenoid squamous cell carcinoma $(10,11)$.

Corneal and conjunctival squamous neoplasms can extend locally to invade the globe and orbit. These tumors can metastasize to regional lymph nodes with a reported incidence of less than $1 \%$, but they are unlikely to metastasize systemically (13). According to the American Joint Committee on Cancer (AJCC)tumor, node, and metastasis (TNM) classification, OSSN is classified based on size and extent of involvement (14). Clinical factors such as tumor nasal location, involvement of the tarsal conjunctiva, presence of positive surgical margins, and high-grade lesions, have been associated with increased risk of recurrence $(10,11$, 
15). The local recurrence rate is reported at about $5 \%$ and regional metastasis at $2 \%$, based on recent therapeutic advances (11).

Surgical removal with cryotherapy to the margins is the gold standard treatment. Plaque brachytherapy is used to control residual disease. Topical chemotherapy is an alternative option for primary treatment and as adjuvant after surgery. Recourse to enucleation or orbital exenteration may be necessary if lesions extend intraocularly and into the orbit (9-11, 15-17).

\section{Melanocytic epithelial tumors}

Melanocytic epithelial lesions have similar histopathological and morphologic appearance to those of the skin, and include conjunctival nevus, complexion-associated melanosis (CAM), primary acquired melanosis (PAM) with or without atypia, and conjunctival melanoma (18).

Conjunctival nevi are benign, circumscribed and typically pigmented lesions, although they may be amelanotic in rare cases. They can be congenital or acquired, and classically locate in the interpalpebral bulbar conjunctiva. They are flat to slightly raised, and usually contain clear cysts and feeder vessels. Importantly, the presence of internal cysts appears to denote a benign process. Similar to nevi of the skin, conjunctival nevi are categorized as junctional, compound, or subepithelial on histopathologic analysis. They can acquire pigment over time; however, the growth of conjunctival nevi is relatively stationary throughout life with an estimated risk of malignant transformation of less than $1 \%(10,11,19)$. Periodic observation is the management of choice. If the excision is performed for cosmesis or suspected growth, it is preferable not to leave any residual lesion $(10,11,19)$.

CAM, also known as racial melanosis, is a benign conjunctival pigmentation commonly found in dark-skinned individuals and showing bilateral involvement. CAM is typically observed around the limbus and variably on the limbal cornea, and it appears flat and non-cystic on examination. Histopathological exams show the presence of benign melanocytes in the basal layer of the epithelium. There are studies demonstrating a mild increase in size with age; however, this condition has not been shown to progress to conjunctival melanoma. Periodic observation is advisable $(10,11,20)$. PAM is an acquired, usually unilateral, pigmented condition, most likely occurring in fair-skinned individuals. It has been associated with neurofibromatosis, thus suggesting a possible origin from the neural crest (11). At examination it appears as a diffuse, flat, and non-cystic area of pigmentation, usually affecting the bulbar conjunctiva $(10,11,19,21)$. This aspect is to be related to the sole intraepithelial involvement of PAM compared to nevus. Moreover, the pigmentation in PAM may wax and wane over time. This condition has been classified in PAM with or without atypia based on nuclear features and growth pattern of melanocytes on histopathological evaluation. PAM with no atypia carries no risk for malignant melanoma progression, whereas risk rises to nearly 50\% in PAM with atypia (10, $11,19)$. PAM with atypia corresponds to melanoma in situ (Tis) in the AJCC-TNM classification of conjunctival melanoma $(22,23)$. Treatment is observation for PAM confined to less than 2 clock hours of conjunctival involvement. In case of PAM involving 2-5 clock hours of conjunctiva, the recommended treatment is surgical excision with cryotherapy to the margins. In case of PAM > 5 clock hours, the treatment of choice is wide incisional biopsy and cryotherapy to all remaining conjunctival pigmentation. As an alternative, application of topical mitomycin $\mathrm{C}(\mathrm{MMC})$ may be considered for treatment of diffuse or multifocal PAM $(19,21)$.

Conjunctival melanoma is a rare tumor accounting for $2-5 \%$ of all ocular malignancies and $5-7 \%$ of all ocular melanomas, but it is among the most common malignant neoplasms of the ocular surface (24). In recent decades, the incidence of conjunctival melanoma has been increasing similar to cutaneous melanoma, while the incidence of uveal melanoma has remained relatively stable. This is thought to be related to the result of environmental exposure to UV light (25-27). Conjunctival melanoma mostly arises from PAM (53-75\%), but can also arise from conjunctival nevi (18-30\%) or de novo $(5 \%)(21,24)$. Importantly, melanoma arising from PAM has been identified to have a higher risk of local recurrence. This tumor is composed of malignant melanocytes with polyhedral, spindle or epithelioid morphology, that violate the epithelial basement membrane on histopathological examination. These cells are positive for $\mathrm{Bcl}-2, \mathrm{~S} 100$, melanA, HMB45, from immunohistochemical studies. Detection of Ki-67 can be of value to assess biological behavior (24). This tumor typically affects elderly patients and presents as a pigmented and nodular lesion with prominent feeding and intrinsic vessels. The most common location is the bulbar conjunctiva near the limbus. Moreover, this tumor 
can be amelanotic or minimally pigmented in up to one-fifth of cases, possibly leading to diagnosis delay $(21,24)$. Conjunctival melanoma can cause distant metastases but also tends to extend locally. The AJCC clinical staging classifies melanomas based on degree of extension in the bulbar or nonbulbar conjunctiva, local invasion, regional lymph nodes or distant metastases $(22,23)$. Sentinel lymph node biopsy is recommended for staging of conjunctival melanomas, and should be especially considered in patients with tumors of more than 10 $\mathrm{mm}$ in diameter and $2 \mathrm{~mm}$ in thickness, non-limbal locations, and in the presence of tumor ulceration (23). The histopathological staging depends on tumor thickness and invasion of the substantia propria. Thickness of invasive tumor is classified as: $\leq$ $0.5 \mathrm{~mm}, 0.5-1.5 \mathrm{~mm}$, and $>1.5 \mathrm{~mm}$. Tumor depth does implicate greater risk for regional and distant metastasis and mortality $(23,28,29)$. In addition, prevalence of epithelioid cells, local recurrence, and non-limbal locations, represent relevant negative prognostic factors $(10,11)$. At 10 years, local recurrence after therapy is esteemed at $50-70 \%$ and distant metastases at 25\% (11, 30-34). Similar to OSSN, the preferred treatment for conjunctival melanoma is complete surgical removal with cryotherapy to the margins. If margins are positive for invasive melanoma, repeated surgical treatment and adjuvant plaque brachytherapy, rather than adjuvant topical chemotherapy, should be performed (35-38). Local tumor recurrence is reported ranging between 18-35\% with this approach $(30,39)$. Radiotherapy is also employed as an adjuvant in case of residual disease. Topical MMC is usually considered for recurrent conjunctival melanoma (21). Enucleation or orbital exenteration may be of choice in case of extensive tumors. Systemic chemotherapy is administered with combination of IFN and interleukin-2 in disseminated melanoma (40-43). Moreover, given the molecular and biological similarities to cutaneous melanoma, targeted therapies including BRAF inhibitors with or without MEK inhibition, and immune checkpoint inhibitors, have recently been investigated in a few case reports for treatment of conjunctival melanoma, with promising results (44).

\section{Stromal tumors}

Stromal tumors of the conjunctiva are rare and include benign and malignant conditions originating from various tissue elements such as vascular and lymphatic, fibrous, neural, histiocytic, myxoid, my- ogenic, and lipomatous tumors, and choristomas. Conjunctival lymphoma is the most frequent malignant stromal tumor of the conjunctiva. It can be primary conjunctival or develop as manifestation of coexisting systemic lymphoma. Approximately $5-15 \%$ of all extranodal lymphomas involve the ocular adnexa, and about $25 \%$ of these involve the conjunctiva (45-49). The most common subtype is low-grade extranodal marginal zone lymphoma, previously known as mucosa-associated lymphoid tissue (MALT) lymphoma, followed by follicular lymphoma, diffuse large B-cell lymphoma, and mantle cell lymphoma. Clinically, it presents as a diffuse, slightly elevated, salmon-colored mass, and it is mostly located in the bulbar conjunctiva and fornixes. $(45,47,50)$. There is no clear clinical difference between conjunctival lymphoma and reactive lymphoid hyperplasia, the latter of which is benign. Therefore, biopsy is mandatory to establish a definite diagnosis $(47,51)$. On histopathological evaluation, conjunctival lymphoma is composed of subepithelial sheets of lymphocytes, and it is classified as reactive lymphoid hyperplasia or malignant lymphoma based on cells morphology and degree of differentiation. Furthermore, most are nonHodgkin's Bcell lymphomas, whereas Hodgkin's Bcell lymphomas and Tcell lymphomas rarely affect the conjunctiva $(10,11,47)$. It is classified according to the Ann Arbor staging system and the AJCC-TNM staging system for ocular adnexa lymphomas (OAL) (52). Importantly for this discussion, forniceal or midbulbar location, multifocality, and bilaterality are relevant prognostic factors for the development of systemic lymphoma. Low dose external beam radiotherapy (EBRT) is the treatment of choice for isolated conjunctival lymphoma or to the orbit including the conjunctiva. Five-year local control rate with radiotherapy alone in the treatment of conjunctival lymphoma ranges from 89 to $100 \%$. In cases of bilateral involvement, systemic treatment is generally selected over bilateral EBRT $(45,48,50)$.

\section{Caruncular tumors}

The caruncle is a peculiar region in the conjunctiva as it contains both mucous membranes and cutaneous structures. It is located in the medial canthus and it is composed of non-keratinized stratified squamous epithelium overlying a stroma of fibroblasts, melanocytes, sebaceous glands, hair follicles, and striated muscle fibers. Among caruncle tumors, nevus and papilloma are the most 
common $(10,11,53,54)$. However, oncocytoma, pyogenic granuloma, inclusion cyst, sebaceous gland hyperplasia and adenoma, have also been reported. The oncocytoma is a benign tumor commonly arising in the lacrimal or salivary glands. When located in the caruncle, it originates from accessory lacrimal glandular tissue, and usually has a blue cystic appearance. Malignant tumors such as squamous cell carcinoma, melanoma, lymphoma, and sebaceous carcinoma are uncommon in the caruncle. The treatment of caruncular tumors depends on diagnosis, thus including either observation or local resection $(10,11,53,54)$.

\section{Metastatic tumors}

Conjunctival metastases are rare, and mostly occur from breast carcinoma and cutaneous melanoma. They appear as single or multiple fleshy, vascularized conjunctival stromal tumors, whereas cutaneous melanoma metastatic to the conjunctiva is usually pigmented $(10,11,48)$.

\section{Secondary tumors}

The conjunctiva can be secondarily involved by tumors affecting adjacent structures. Specifically, it can be involved by extraocular extension from intraocular tumors or by extension from eyelid and orbital tumors. Of relevance, the sebaceous gland carcinoma of the eyelid is capable of pagetoid growth into the conjunctival epithelium. Furthermore, conjunctival infiltration following direct invasion of the sclera has been described in uveal melanoma. Moreover, rhabdomyosarcoma of the orbit can occasionally present with conjunctival involvement as first manifestation of disease $(10,11)$.

\section{DIAGNOSIS}

\section{Observation}

For smaller lesions ( $\leq 4$ clock hours limbal tumor or $\leq 15 \mathrm{~mm}$ basal dimension) that appear benign such as dermoid, or nevus, a diagnostic biopsy is usually not necessary. Periodic observation with slit-lamp photographs every 6 or 12 months looking for growth or malignant change is the optimal management of these conditions.

\section{Surgical biopsy}

Confirmation by histopathologic analysis on surgical biopsy is the gold standard for diagnosis. When a smaller tumor ( $\leq 4$ clock hours limbal tumor or $\leq$ $15 \mathrm{~mm}$ basal dimension) does worth a biopsy, excisional biopsy is generally preferable over incisional biopsy. Among benign and malignant lesions to be treated with excisional biopsy are symptomatic dermoid, choristoma, steroid-resistant pyogenic granuloma, SCC, and conjunctival melanoma. Incisional biopsy is reserved for larger tumors (> 4 clock hour limbal tumor or $>15 \mathrm{~mm}$ basal dimension) that are symptomatic or suspected to be malignant. Examples include PAM, and large SCC. Also, for large or recurrent lesions, excisional biopsy leads to increased risks of limbal stem cell deficiency, symblepharon, and scarring, as well as requiring mucous membrane grafts from the contralateral conjunctiva, buccal mucosa, or amniotic membrane. Incisional biopsy is also appropriate for conditions that are rather managed with radiotherapy or chemotherapy, such as lymphoid tumors, conjunctival invasion by sebaceous gland carcinoma or metastatic tumors $(10,21)$. The use of incisional biopsy should be avoided for conjunctival melanoma, as this can increase the risk of tumor recurrence (30).

\section{Cytology}

Less invasive modalities including fine needle aspiration biopsy and impression cytology can provide useful information based on sampling of a few cells $(1,55,56)$. However, these techniques have limited applicability due to the sampling of surface cells only, thus not allowing distinction of carcinoma in situ from infiltrating carcinoma.

\section{Non-invasive diagnostic modalities}

Non-invasive diagnostic approaches have been explored in recent years, and include in vivo confocal microscopy (IVCM), ultrasound biomicroscopy (UBM), and anterior segment high-resolution optical coherence tomography (HR-OCT) $(1,9,57,58)$.

\section{Confocal microscopy (IVCM)}

IVCM is an imaging method, which enables morphological and quantitative analysis of ocular surface structures and cells. It allows examination of tissue sections by selecting the depth of interest, and provides images of 1-2 $\mu \mathrm{m}$ lateral resolution and 5-10 $\mu \mathrm{m}$ axial resolution. The largest studies to date of IVCM for OSSN, conjunctival melanocytic lesions and lymphoma, demonstrated that IVCM cannot replace biopsy although it has some utility as an adjuvant for histology. $(1,57,59)$. 


\section{Ultrasound biomicroscopy (UBM)}

UBM is an ultrasound modality that uses a higher frequency transducer $(35-100 \mathrm{MHz}$ ) than A-scan or B scan $(10 \mathrm{MHz})$. This results in up to $20 \mu \mathrm{m}$ axial and $50 \mu \mathrm{m}$ lateral resolutions, and depth of tissue penetration of 4-5 $\mathrm{mm}$. This technique has the ability to delineate tumor posterior margin and extent even in case of densely pigmented lesions or corneal opacities. This improves detection of tumor invasion, however, the resolution of intralesional details is limited $(1,58)$.

\section{Anterior segment high-resolution OCT (HR-OCT)}

HR-OCT is non-invasive, non-contact device that provides cross-sectional images of the ocular surface with a resolution of 5 to $10 \mu \mathrm{m}$. Recently, the advent of ultra-high resolution (3-5 $\mu \mathrm{m}$ ) OCT (UHROCT) using spectral-domain technology has enabled more detailed evaluation (60-62). HR-OCT is able to detect epithelial thickening and differentiating epithelial from subepithelial lesions of the conjunctiva and cornea $(1,9,63)$. It can be used for OSSN detection in the presence of concomitant ocular surface disease, and in monitoring response to treatment. The classical findings of OSSN on HR-OCT consist of epithelial hyperreflectivity and thickening, and an abrupt transition between normal and cancerous epithelium $(1,63)$. Limitations of this technology for OSSN include difficulty in imaging the posterior border of thick, keratinized, and pigmented lesions due to shadowing of the image. HR-OCT can be helpful in differentiating between epithelial lesions of melanocytic origin, although it has the limitation of shadowing in densely pigmented lesions. For conjunctival nevi, this technique reveals intrinsic cysts even when they are not visible on clinical exam, as well as hyperreflective basal epithelial layers. In PAM, HR-OCT features are that of a uniform hyper-reflective band along the basal epithelium, with normal overlying epithelium and absence of cysts. However, HR-OCT is not able to evaluate atypia. For conjunctival melanoma, HR-OCT allows for detection of a hyper-reflective epithelium of variable thickening overlying a hyper-reflective sub-epithelial mass and absence of cysts. Also, HR-OCT has been studied in the diagnosis of conjunctival lymphoma, but it showed limitations including the inability to distinguish benign reactive lymphoid hyperplasia from conjunctival lymphoma, and poor detection of underlying tissues due to shadowing effect in case of thick lesions $(1,9,58,61-63)$.

\section{THERAPY}

Local excision with cryotherapy to the margins has been the mainstay treatment of ocular surface cancers, however, topical chemotherapy alone is now gaining increasing consensus among specialists in the field. Surgical removal has the advantage of serving as both as diagnostic and therapeutic procedure. However, surgery has potential disadvantages including limbal stem cell deficiency or conjunctival scarring, and it can leave residual disease leading to tumor recurrence $(10,11,48)$.

\section{Surgical techniques}

Primary tumors of the ocular surface mostly arise in bulbar conjunctiva near the limbus. The treatment of choice for resection of limbal tumors is the 'no touch, en-bloc tumor excision' technique. This procedure involves excision of large margins with 'en-bloc' removal to avoid seeding of tumor cells. A conjunctival incision based at the limbus is made at least $4 \mathrm{~mm}$ outside the tumor margin. The incision is carried out through the episcleral plane, so that full thickness conjunctiva and Tenon's fascia are included in the excised tissue. For any corneal involvement, application of absolute alcohol and then localized epitheliectomy $2 \mathrm{~mm}$ outside the corneal component is recommended. In advanced cases, lamellar corneal excision may be required for complete resection. If there is any scleral adhesion or corneal stroma involvement, a thin lamella of sclera is removed (0.2-0.3 mm depth), to achieve tumor-free margins and decrease the chance for tumor recurrence. Double freeze-thaw cryotherapy is usually performed to the borders of the remaining bulbar conjunctiva to eliminate subclinical tumor cells. It is not necessary to treat the corneal margins with cryoapplication. Limbal cryotherapy should be limited to 6 clock hours. The excision base is generally treated with absolute alcohol wash to avoid cryotherapy directly on the sclera. After this, conjunctival reconstruction should be performed with clean instruments to avoid tumor seeding $(10,11)$. In case of forniceal tumors, the technique for resection consists of complete tumor excision with wide margins and cryotherapy to the margins. Lesions involving the tarsal conjunctiva may require a posterior lamellar eyelid resection. If lesions involve the eyelid margin or extend to the skin, more extensive full thickness resections and reconstructions are mandatory. If pathological evaluation 
reveals tumor cells at the conjunctival margin, additional surgery or postoperative topical chemotherapy may be used.

Enucleation is reserved to patients with deep corneal or scleral tumor invasion or intraocular extension. Orbital exenteration is indicated in case of extensive tumor recurrences, non-resectable tumor without evidence of metastasis, or patients with painful eyes and unacceptable cosmesis. Before and during exenteration, the nasal lacrimal system should be evaluated for signs of disease. When the disease is exclusively conjunctival and/or orbital, a lid sparing exenteration can offer a socket to allow the placement of a prosthesis. Importantly, external beam radiotherapy (EBRT) can represent a valid alternative and/or adjunct to exenteration in cases with extensive palpebral, forniceal, conjunctival, or caruncular involvement $(10,11,16,48)$.

\section{Topical chemotherapy}

In recent years, sole topical chemotherapy has proven to achieve complete tumor resolution and low recurrence rate with less injury $(35,64-66)$. This approach is preferred in diffuse and multifocal lesions, and no defined tumor margins. Topical chemotherapy allows treatment of the entire ocular surface and lower risk for limbal stem cell impairment. With topical treatment, however, the duration is longer and requires compliance of the patient. Furthermore, this treatment can be employed preoperatively as chemoreduction, and postoperatively, when margins are positive. However, caution should be paid as corneal melt, scleral melt, and cataract can occur if these agents are used with open conjunctival wounds or used excessively. Topical chemotherapy includes the use of interferon alpha 2b (IFNa-2b), 5-fluorouracil (5-FU) 1\%, and mitomycin C (MMC). Their beneficial role involves immunomodulation, anti-proliferative, and anti-viral activity. All of these drugs require compounding. 5-FU has some advantages over MMC and IFNa-2b, as it is the most inexpensive, does not require refrigeration, and involves less frequent administration. MMC has more common and severe adverse effects than IFa-2b or 5-FU, including corneal toxicity, limbal stem cell deficiency, and punctal stenosis. Side effects of topical 5-FU include pain and redness at the instillation side, eyelid swelling, conjunctival congestion, filamentary keratitis and, rarely, superficial stromal melting. Punctal or canalicular stenosis can occur with systemic 5-FU treatment, but not with topical 5-FU use. IFNa-2b is less toxic compared to both topical 5-FU and MMC.
However, its use is often limited by cost and access to the drug. IFNa-2b can be used as topical or subconjunctival/perilesional formulation in the management of ocular surface tumors. When administered topically, IFNa-2b has the advantage of ease of use and minimal to no side effects, but it requires longer duration of treatment compared to 5-FU and MMC. Conversely, subconjunctival injections have more side effects than drops, including flu-like malaise that lasts for approximately $48 \mathrm{~h}$, but have the benefits of faster resolution, better compliance, and no need for compounding. There is evidence on efficacy of topical chemotherapy for various premalignant and malignant lesions of the ocular surface, such as OSSN, diffuse and multifocal PAM with atypia, and recurrent conjunctival melanoma $(16,35,36,64-68)$.

\section{Ocular surface squamous neoplasia (OSSN)}

Topical 5-FU is generally used as first line agent in the primary treatment of preinvasive and invasive OSSN as well as an adjuvant after surgical excision. This drug is usually administrated at a concentration of $1 \%$ in a cyclical pattern four times daily for one week followed by a drug holiday for three weeks. This monthly cycle is repeated on average of 4 to 6 cycles based on clinical response. Alternative regimens include administration of topical 5-FU 4 times daily for 2 days to 4 weeks, with variable weeks off $(16,65-68)$. Recently, subconjunctival/perilesional 5-FU injections for treatment of OSSN have shown to be effective and safe in the long term (69). IF$\mathrm{Na}-2 \mathrm{~b}$ is a valid alternative to 5-FU for treatment of OSSN, however, it may have decreased efficacy compared to 5-FU in patients with underlying immunosuppression $(65,67,68,70)$. IFNa-2b for OSSN can be used as topical eye drops, subconjunctival/ perilesional injections, or a combination of both.

Topical and subconjunctival/perilesional IFNa-2b can be used as primary or adjuvant therapies. Treatment with topical IFNa-2b is generally administered at a dose of 1 million $\mathrm{IU} / \mathrm{mL}$ four times a day continuously until one or two months after clinical resolution. The average time for clinical resolution is about 4 months. A dosage of topical 2-3 million IU/ $\mathrm{ml}$ demonstrated similar efficacy. When used as a post-surgical adjuvant, topical IFNa-2b 1 million IU/ $\mathrm{ml}$ is administered four times daily for a duration of 2 months post-operatively. IFNa-2b injected subconjunctival/perilesional is administered at a dose of 3 million IU/0.5 ml weekly until clinical resolution of OSSN, usually requiring 4 to 5 injections. The use of higher concentrations has also been reported, with 
the highest being 10 million IU given once a month. There are evidences suggesting the use of intralesional injection of 3 million IU/0.5 ml or 10 million IU/ month IFN $a-2 b$ combined with 1 million IU topical IFN $a-2 b$, as a primary modality for unresectable extensive tumors. It also helps for reduction of tumor size prior to complete surgical excision (70).

MMC is generally considered as second line agent for OSSN. MMC can be used for primary treatment of OSSN, but can also be used as an adjuvant agent intraoperatively, and post-operatively in patients with positive conjunctival margins $(65,67,68,71$, 72). When used as a primary therapy for OSSN, MMC is generally prescribed at a concentration between 0.02 and $0.04 \%$. MMC is administered 4 times a day for 1 week followed by 2-3 weeks of no treatment. The length of the drug holiday depends on how long it takes the eye to recover from the 1 week of treatment. It usually takes a total of 3 cycles for the tumor to resolve. Alternative regimens include 7-14 day cycles. MMC can also be used intraoperatively during tumor excision, typically soaked on a sponge at a concentration of $0.02 \%$ and applied to the conjunctival margins for 1-3 min. Postoperatively, MMC can be used in patients with positive margins after the surface heals. The dose and protocol during post-operative use are similar to primary use $(65,67,68)$. Topical chemotherapeutic agents for OSSN are listed in Table 3.

\section{Melanocytic epithelial tumors}

Topical chemotherapy is usually used as an adjuvant for conjunctival melanoma if surgical margins demonstrate PAM with atypia, but it can also be employed as a primary treatment in cases of diffuse or multifocal PAM with atypia and recurrent conjunctival melanoma. A commonly used dosing regimen for treatment of melanocytic lesions is two-week cycles of $0.04 \%$ MMC 4 times a day, followed by treatment discontinuation for 14 days $(35,36,73)$. The use of topical IFNa-2b has been reported as a less toxic adjunctive therapy for melanocytic lesions, but evidence is limited $(35,74-$ 76). The use of 5-FU has not been investigated for ocular surface melanocytic neoplasms.

\section{Radiotherapy}

There are two forms of radiotherapy usually employed for the treatment of ocular surface tumors, namely EBRT and plaque brachytherapy $(44,77)$. EBRT is a method for delivering high-energy $x$-rays to cancer cells while sparing surrounding tissues. It is

\begin{tabular}{|c|c|c|c|}
\hline DRUGS & FORMULATION & DOSAGE & SIDE EFFECTS \\
\hline 5-FU & $\begin{array}{l}\text { Topical: } 1 \% \text { drops } \\
\text { Subconjunctival/perilesional } \\
\text { Injections: } 25 \mathrm{mg} / \mathrm{mL} \text { at } \\
\text { certain intervals. }\end{array}$ & $\begin{array}{l}4 \text { times a day for } 1 \text { week and } 3 \\
\text { weeks off. Mean } 4-6 \text { cycles } \\
\text { (alternative: } 4 \text { times daily from } \\
2 \text { days to } 4 \text { weeks and variable } \\
\text { weeks off). }\end{array}$ & $\begin{array}{l}\text { Pain and redness at the } \\
\text { instillation side, eyelid swelling, } \\
\text { conjunctival congestion, } \\
\text { filamentary keratitis and, } \\
\text { rarely, superficial stromal } \\
\text { melting. }\end{array}$ \\
\hline IFN $a-2 b$ & $\begin{array}{l}\text { Topical: } 1 \mathrm{MIU} / \mathrm{ml} \text { (Alternative: } \\
\text { 2-3 MIU/ml). } \\
\text { Subconjunctival injections: } \\
3 \mathrm{MIU} / 0.5 \mathrm{ml} \text { (alternative: } 10 \\
\text { MIU/month). }\end{array}$ & $\begin{array}{l}\text { Topical: } 4 \text { times a day continuously } \\
\text { until 1-2 months after resolution. } \\
\text { Subconjunctival: } 3 \text { MIU/0.5 ml } \\
\text { weekly injections until resolution } \\
\text { (mean 4-5 weeks) or } 10 \text { MIU } \\
\text { monthly. } \\
\text { Topical post-surgical: } 4 \text { times a day } \\
\text { continuously for } 2 \text { months. }\end{array}$ & $\begin{array}{l}\text { Minimal side effects for drops, } \\
\text { flu-like malaise with injection. }\end{array}$ \\
\hline MMC & Topical: 0.02-0.04\% drops & $\begin{array}{l}4 \text { times a day for } 1 \text { week followed } \\
\text { by } 2-3 \text { weeks off until the eye } \\
\text { is quiet. Usually } 3 \text { cycles until } \\
\text { resolution (Alternative: } 7-14 \text { day } \\
\text { cycles). }\end{array}$ & $\begin{array}{l}\text { Corneal toxicity, limbal stem } \\
\text { cell deficiency, and punctal } \\
\text { stenosis. }\end{array}$ \\
\hline
\end{tabular}

Table III. Topical chemotherapeutic agents for OSSN (16,65-72). 
generally used to treat isolated conjunctival lymphoma and locally extensive, non-resectable tumors. Plaque brachytherapy, on the other hand, is provided with a device filled with radioactive seeds sutured to the ocular surface, Radiation sources include isotopes of iodine-125, palladium-103, strontium-90, and ruthenium-106. Unlike topical chemotherapy, plaque brachytherapy has the ability to treat deep in the sclera. This procedure is considered in patients with positive surgical margins and in those showing multiple recurrences, and it should be delayed until conjunctiva has healed $(10,21)$. More recently, radiotherapy techniques via surface applicator have been developed to avoid the use of an attached plaque (77). Side effects of radiotherapy include dry eye syndrome, punctate epithelial abnormalities and corneal ulceration, retinopathy, orbital fat tissue atrophy, and cataract development. In order to reduce radiation toxicity, a lower dose or smaller daily fractions can be used (77).

\section{CONCLUSIONS}

Tumors of the ocular surface include a broad clinical spectrum. The diagnosis of ocular surface tumors is primarily based on clinical evaluation and histological confirmation. Recently, new non-invasive diagnostic approaches including HR-OCT showed promise for use as adjuvant for histology. Treatment of ocular surface tumors is classically based on local excision with cryotherapy to the margins and/or radiotherapy. Topical chemotherapy recently demonstrated complete tumor resolution and a low recurrence rate with less injury if compared to surgical removal.

\section{ETHICS}

\section{Fundings}

There were no institutional or private fundings for this article.

\section{Conflict of interests}

The authors have declared no conflict of interests.

\section{Availability of data and material}

All the data supporting the findings of this study are available within the article and can be shared just before a reasonable request to the corresponding author.

\section{Authors' contribution}

Study conception and design: MS, FM, AL. Drafting of manuscript: FM, MS, AVC. Acquisition of images: MS, PS. Critical revision: MS, AL. All authors contributed to refinement of the study and approved the final manuscript. This manuscript has been read and approved by all the authors and each author believes that the manuscript represents honest work. All authors meet the requirements for authorship and all express full consent for publication on jour esteemed Journal. All the authors contributed equally to conception, data collection, analysis and writing of this paper.Ethical approvalThe study was realized in full compliance with the Declaration of Helsinki.

\section{Consent to participate}

Informed consent to publish personal or clinical details along with any identifying images was obtained from each patient. 


\section{REFERENCES}

1. Nanji AA, Mercado C, Galor A, Dubovy S, Karp CL. Updates in ocular surface tumor diagnostics. Int Ophthalmol Clin 2017;57(3):47-62. Available at: https://pubmed.ncbi.nlm.nih. gov/28590280/. Last access: 15 Feb 2021.

2. Shields JA, Shields CL, Kluwer W, et al. Eyelid, Conjunctival, and Orbital Tumors 2016. Available at: https://books.google.com/books?hl=it\&lr=\&id =Gfd_oRby2e0C\&oi=fnd\&pg=PA3\&ots=735p2Fn3Hn\&sig=0RdsI2u63XFS24YQqISNOhRZVPE. Last access: 15 Feb 2021.

3. Lee GA, Hirst LW. Ocular surface squamous neoplasia. Surv Ophthalmol 1995;39(6):42950. Available at: https://pubmed.ncbi.nlm.nih. gov/7660300/. Last access: 15 Feb 2021.

4. Chalkia AK, Bontzos G, Spandidos DA, Detorakis ET. Human papillomavirus infection and ocular surface disease (Review). Int J Oncol 2019;54(5):1503-10. Available at: https://pubmed.ncbi.nlm.nih.gov/30896784/. Last access: 15 Feb 2021.

5. Rathi SG, Ganguly Kapoor A, Kaliki S. Ocular surface squamous neoplasia in HIVinfected patients: Current perspectives. Vol. 10, HIV/ AIDS-Research and Palliative Care. Dove Medical Press Ltd.;2018;p. 33-45. Available at: https://pubmed.ncbi.nlm.nih.gov/29559813/. Last access: 15 Feb 2021.

6. Basti $S$, Macsai MS. Ocular surface squamous neoplasia: A review. Cornea 2003;22:687-704. Available at: https://pubmed.ncbi.nlm.nih.gov /14508267/. Last access: 15 Feb 2021.

7. Carreira H, Coutinho F, Carrilho C, Lunet N. HIV and HPV infections and ocular surface squamous neoplasia: Systematic review and meta-analysis. Br J Cancer 2013;109(7):1981-8. Available at: https://pubmed.ncbi.nlm.nih.gov /24030075/. Last access: 15 Feb 2021.

8. Gichuhi S, Ohnuma S ichi, Sagoo MS, Burton MJ. Pathophysiology of ocular surface squamous neoplasia. Vol. 129, Experimental Eye Research. Academic Press; 2014;172-82. Available at: https://pubmed.ncbi.nlm.nih.gov/25447808/. Last access: 15 Feb 2021.

9. Sayed-Ahmed IO, Palioura S, Galor A, Karp CL. Diagnosis and medical management of ocular surface squamous neoplasia. Expert Rev Ophthalmol, Taylor and Francis Ltd 2017;12: 11-9. Available at: https://pubmed.ncbi.nlm.nih. gov/28184236/. Last access: 15 Feb 2021.

10. Shields CL, Shields JA. Tumors of the conjunctiva and cornea. Surv Ophthalmol 2004;49(1):324. Available at: https://pubmed.ncbi.nlm.nih. gov/14711437/. Last access: 15 Feb 2021.

11. Honavar SG, Manjandavida FP. Tumors of the ocular surface: A review. In: Indian Journal of Ophthalmology. Medknow Publications; 2015;187203. Available at: https://pubmed.ncbi.nlm.nih. gov/25971163/. Last access: 15 Feb 2021.

12. Akpek EK, Polcharoen W, Chan R, Foster CS. Ocular surface neoplasia masquerading as chronic blepharoconjunctivitis. Cornea 1999;18(3):282-8. Available at: https://pubmed.ncbi.nlm.nih.gov/10336029/. Last access: 15 Feb 2021.

13. Tunc M, Char DH, Crawford B, Miller T. Intraepithelial and invasive squamous cell carcinoma of the conjunctiva: Analysis of 60 cases. $\mathrm{Br}$ J Ophthalmol 1999;83(1):98-103. Available at: https://pubmed.ncbi.nlm.nih.gov/10209445/. Last access: 15 Feb 2021.

14. Singh S, Mohamed A, Kaliki S. Ocular surface squamous neoplasia: analysis based on the 8th American Joint Committee on Cancer classification. Int Ophthalmol 2019;39(6):1283-91. Available at: https://pubmed.ncbi.nlm.nih. gov/29749567/. Last access: 15 Feb 2021.

15. Yin VT, Merritt HA, Sniegowski M, Esmaeli B. Eyelid and ocular surface carcinoma: Diagnosis and management. Clin Dermatol 2015;33(2):159-69. Available at: https://pubmed.ncbi.nlm.nih.gov/25704936/. Last access: 15 Feb 2021.

16. Al Bayyat G, Arreaza-Kaufman D, Venkateswaran N, Galor A, Karp CL. Update on pharmacotherapy for ocular surface squamous neoplasia. Eye Vis 2019;6(1). Available at: https://pubmed.ncbi.nlm.nih.gov/31417938/. Last access: 15 Feb 2021.

17. Cicinelli MV, Marchese A, Bandello F, Modorati G. Clinical Management of Ocular Surface Squamous Neoplasia: A Review of the Current Evidence. Ophthalmol Ther, Springer Healthcare 2018;7:247-62. Available at: https://pubmed.ncbi.nlm.nih.gov/30030703/. Last access: 15 Feb 2021.

18. Conjunctival Pigmented Lesions: Diagnosis and Management-American Academy of Ophthal- 
mology. Available at: https://www.aao.org/eyenet/article/conjunctival-pigmented-lesions-diagnosis-managemen. Last access: 15 Feb 2021.

19. Kao A, Afshar A, Bloomer M, Damato B. Management of primary acquired melanosis, nevus, and conjunctival melanoma. Cancer Control 2016;23(2):117-25. Available at: https:// pubmed.ncbi.nlm.nih.gov/27218788/. Last access: 15 Feb 2021.

20. Conjunctival Pigmented Lesions: Diagnosis and Management-American Academy of Ophthalmology. Available at: https://www.aao.org/eyenet/article/conjunctival-pigmented-lesions-diagnosis-managemen. Last access: 28 Jan 2021.

21. Cohen VML, O'Day RF. Management Issues in Conjunctival Tumours: Conjunctival Melanoma and Primary Acquired Melanosis. Ophthalmol Ther 2019;8(4):501-10. Available at: https://pubmed.ncbi.nlm.nih.gov/31691901/. Last access: 15 Feb 2021.

22. Coupland SE, Barnhill R, Conway RM, et al. Conjunctival melanoma-Google Scholar. Available at: https://scholar.google.it/ scholar?hl=it\&as_sdt $=0 \% 2 \mathrm{C} 5 \& \mathrm{q}=$ Conjuncti$\mathrm{val}+$ melanoma+SE+Coupland\%2C+R+Barnhill\%2C+RM+Conway\%2C+B+Damato...+-+AJC$\mathrm{C}+$ Canger + Staging $+\ldots \% 2 \mathrm{C}+2017 \& b \operatorname{btnG}=$. Last access: 15 Feb 2021.

23. Esmaeli B, Rubin ML, Xu S, et al. Greater Tumor Thickness, Ulceration, and Positive Sentinel Lymph Node Are Associated with Worse Prognosis in Patients with Conjunctival Melanoma: Implications for Future AJCC Classifications. Am J Surg Pathol 2019;43(12):1701-10. Available at: https://pubmed.ncbi.nlm.nih. gov/31425167/. Last access: 15 Feb 2021.

24. Kaštelan S, Gverović Antunica A, Beketić Orešković L, Salopek Rabatić J, Kasun B, Bakija I. Conjunctival Melanoma-Epidemiological Trends and Features. Pathol Oncol Res, Springer Netherlands 2018;24:787-96. Available at: https://pubmed.ncbi.nlm.nih.gov/29802540/. Last access: 15 Feb 2021.

25. Grimes JM, Shah N V, Samie FH, Carvajal RD, Marr BP. Conjunctival Melanoma: Current Treatments and Future Options. Am J Clin Dermatol, Adis 2020;21:371-81. Available at: https://pubmed.ncbi.nlm.nih.gov/31965542/. Last access: 15 Feb 2021.
26. Rossi E, Schinzari G, Maiorano BA, et al. Conjunctival melanoma: Genetic and epigenetic insights of a distinct type of melanoma. In J Mol Sci, MDPI AG 2019;20. Available at: https:// pubmed.ncbi.nlm.nih.gov/31683701/. Last access: 15 Feb 2021.

27. Gkiala A, Palioura S. Conjunctival melanoma: Update on genetics, epigenetics and targeted molecular and immune-based therapies. Clin Ophthalmo, Dove Medical Press Ltd 2020;14:3137-52. Available at: https://pubmed.ncbi.nlm.nih. gov/33116365/. Last access: 26 Dec 2020.

28. Paridaens ADA, Minassian DC, McCartney ACE, Hungerford JL. Prognostic factors in primary malignant melanoma of the conjunctiva: A clinicopathological study of 256 cases. $\mathrm{Br}$ J Ophthalmol 1994;78(4):252-9. Available at: https://pubmed.ncbi.nlm.nih.gov/8199108/. Last access: 15 Feb 2021.

29. Tuomaala S, Toivonen P, Al-Jamal R, Kivelä T. Prognostic significance of histopathology of primary conjunctival melanoma in caucasians. Curr Eye Res 2007;32(11):939-52. Available at: https://pubmed.ncbi.nlm.nih.gov/18027170/. Last access: 15 Feb 2021.

30. Shields CL, ShieldsJA, Gündüz K, et al. Conjunctival melanoma: Risk factors for recurrence, exenteration, metastasis, and death in 150 consecutive patients. Arch Ophthalmol 2000;118(11):1497507. Available at: https://pubmed.ncbi.nlm.nih. gov/11074806/. Last access: 15 Feb 2021.

31. Shields CL, Demirci $H$, Karatza E, Shields JA. Clinical survey of 1643 melanocytic and nonmelanocytic conjunctival tumors. Ophthalmol 2004;111(9):1747-54. Available at: https://pubmed.ncbi.nlm.nih.gov/15350332/. Last access: 15 Feb 2021.

32. Shields CL, Belinsky I, Romanelli-Gobbi M, et al. Anterior segment optical coherence tomography of conjunctival nevus. Ophthalmol 2011;118(5):915-9. Available at: https://pubmed.ncbi.nlm.nih.gov/21146221/. Last access: 15 Feb 2021.

33. Lommatzsch PK, Lommatzsch RE, Kirsch I, Fuhrmann P. Therapeutic outcome of patients suffering from malignant melanomas of the conjunctiva. Br J Ophthalmol 1990;74(10):6159. Available at: https://pubmed.ncbi.nlm.nih. gov/2285686/. Last access: 15 Feb 2021. 
34. Norregaard JC, Gerner N, Jensen OA, Prause JU. Malignant melanoma of the conjunctiva: Occurrence and survival following surgery and radiotherapy in a Danish population. Graefe's Arch Clin Exp Ophthalmol 1996;234(9):569-72.

35. Vora GK, Demirci H, Marr B, Mruthyunjaya P. Advances in the management of conjunctival melanoma. Surv Ophthalmol 2017;62(1):2642. Available at: https://linkinghub.elsevier. com/retrieve/pii/S0039625716300583. Last access: 17 Feb 2021.

36. Chalasani R, Giblin M, Conway RM. Role of topical chemotherapy for primary acquired melanosis and malignant melanoma of the conjunctiva and cornea: Review of the evidence and recommendations for treatment. Clin Experim Ophthalmol 2006;34:708-14.

37. Kim J. Topical treatment options for conjunctival neoplasms. Clin Ophthalmol 2008;2(3):503. Available at: https://pubmed.ncbi.nlm.nih. gov/19668748/. Last access: 17 Feb 2021.

38. Rodríguez-Ares T, Touriño R, De Rojas V, Becerra $\mathrm{E}$, Capeans $\mathrm{C}$. Topical mitomycin $\mathrm{C}$ in the treatment of pigmented conjunctival lesions. Cornea 2003;22(2):114-7. Available at: https:// pubmed.ncbi.nlm.nih.gov/12605043/. Last access: 17 Feb 2021.

39. De Potter P, Shields JA, Shields CL, Menduke $\mathrm{H}$. Clinical predictive factors for development of recurrence and metastasis in conjunctival melanoma: A review of 68 cases. $\mathrm{Br} J$ Ophthalmol, BMJ Publishing Group 1993;77:624-30. Available at: https://pubmed.ncbi.nlm.nih. gov/8218029/. Last access: 17 Feb 2021.

40. Zeng Y, Hu C, Shu L, et al. Clinical treatment options for early-stage and advanced conjunctival melanoma. Surv Ophthalmol, Elsevier Inc 2020. Available at: https://pubmed.ncbi.nlm. nih.gov/32980421/. Last access: 17 Feb 2021.

41. Oellers $\mathrm{P}, \mathrm{Karp} C L$. Management of pigmented conjunctival lesions. Ocular Surface. Elsevier Inc 2012;10:251-63. Available at: https:// pubmed.ncbi.nlm.nih.gov/23084146/. Last access: 15 Feb 2021.

42. Harooni $H$, Schoenfield LR, Singh AD. Current appraisal of conjunctival melanocytic tumors: Classification and treatment. Future Oncol 2011;7:43546. Available at: https://pubmed.ncbi.nlm.nih. gov/21417906/. Last access: 15 Feb 2021.
43. Grin JM, Grant-Kels JM, Grin CM, Berke A, Kels BD. Ocular melanomas and melanocytic lesions of the eye. J Am Acad Dermatol 1998;38(5 I):71630. Available at: https://pubmed.ncbi.nlm.nih. gov/9591817/. Last access: 15 Feb 2021.

44. Koç i, Kıratlı H. Current management of conjunctival melanoma part 2: Treatment and future directions. Tur J Ophthalmol, Turkish Ophthalmology Society2020;50:362-70. Available at: https://pubmed.ncbi.nlm.nih. gov/33389937/. Last access: 15 Feb 2021.

45. Tanenbaum RE, Galor A, Dubovy SR, Karp CL. Classification, diagnosis, and management of conjunctival lymphoma. Eye Vis 2019;6(1). Available at: https://pubmed.ncbi.nlm.nih. gov/31372366/. Last access: 15 Feb 2021.

46. Sjö LD, Ralfkiaer E, Prause JU, et al. Increasing incidence of ophthalmic lymphoma in Denmark from 1980 to 2005. Investig Ophthalmol Vis Sci 2008;49(8):3283-8. Available at: https:// pubmed.ncbi.nlm.nih.gov/18390644/. Last access: 15 Feb 2021.

47. Verdijk RM. Lymphoproliferative tumors of the ocular adnexa. Asia-Pacific J Ophthalmol 2017;6:132-42. Available at: https://pubmed. ncbi.nlm.nih.gov/28399341/. Last access: 15 Feb 2021.

48. Maheshwari A, Finger PT. Cancers of the eye. Cancer Metastasis Rev, Springer New York LLC 2018;37:677-90. Available at: https://pubmed. ncbi.nlm.nih.gov/30203109/. Last access: 15 Feb 2021.

49. Rubinstein TJ, Aziz HA, Bellerive C, et al. Ocular/adnexal lymphoma: dissimilar to systemic lymphoma. Surv Ophthalmol, Elsevier USA 2018;63:381-8. Available at: https://pubmed. ncbi.nlm.nih.gov/28837797/. Last access: 15 Feb 2021.

50. Kirkegaard MM, Coupland SE, Prause JU, Heegaard S. Malignant lymphoma of the conjunctiva. Surv Ophthalmol, Elsevier USA 2015;60:44458. Available at: https://pubmed.ncbi.nlm.nih. gov/26003619/. Last access: 15 Feb 2021.

51. Andrew NH, Coupland SE, Pirbhai A, Selva D. Lymphoid hyperplasia of the orbit and ocular adnexa: A clinical pathologic review. Surv Ophthalmol 2016;61(6):778-90. Available at: https://pubmed.ncbi.nlm.nih.gov/27127077/. Last access: 15 Feb 2021. 
52. Kwon M, Lee JS, Lee C, Yoon DH, Sa HS. Prognostic factors for relapse and survival among patients with ocular adnexal lymphoma: Validation of the eighth edition of the American Joint Committee on Cancer (AJCC) TNM classification. Br J Ophthalmol 2021;105(2):279-84. Available at: https://pubmed.ncbi.nlm.nih.gov/32327417/. Last access: 15 Feb 2021.

53. Shields CL, Shields JA. Tumors of the caruncle. In Ophthalmol Clin 1993;33:31-6. Available at: https://pubmed.ncbi.nlm.nih.gov/8407190/. Last access: 15 Feb 2021.

54. Kapil JP, Proia AD, Puri PK. Lesions of the lacrimal caruncle with an emphasis on oncocytoma. Am J Dermatopathol 2011;33(3):227-35. Available at: https://pubmed.ncbi.nlm.nih. gov/21522047/. Last access: 15 Feb 2021.

55. Mathew A, Stumpf T, McGhee C. Impression cytology: Implications for ocular surface squamous neoplasia (12). Br J Ophthalmol, BMJ Publishing Group 2008;92:157-8. Available at: https://pubmed.ncbi.nlm.nih.gov/18156392/. Last access: 16 Feb 2021.

56. Tananuvat N, Lertprasertsuk N, Mahanupap P, Noppanakeepong P. Role of impression cytology in diagnosis of ocular surface neoplasia. Cornea 2008;27:269-74. Available at: https:// pubmed.ncbi.nlm.nih.gov/18362650/. Last access: 17 Feb 2021.

57. Tanaka S, Kohanim S. The role of confocal microscopy in diagnosing ocular surface tumors. Int Ophthalmol Clin 2017;57(1):75-85. Available at: https://pubmed.ncbi.nlm.nih. gov/27898615/. Last access: 17 Feb 2021.

58. Rao R, Saeed HN, Chodosh J. Advances in Imaging of Ocular Surface Tumors. Int Ophthalmol Clin 2017;57(4):21-9. Available at: https:// pubmed.ncbi.nlm.nih.gov/28885244/. Last access: 17 Feb 2021.

59. Xu Y, Zhou Z, XuY, et al. The clinical value of in vivo confocal microscopy for diagnosis of ocular surface squamous neoplasia. Eye 2012;26(6):7817. Available at: https://pubmed.ncbi.nlm.nih. gov/22402703/. Last access: 17 Feb 2021.

60. Thomas BJ, Galor A, Nanji AA, et al. Ultra high-resolution anterior segment optical coherence tomography in the diagnosis and management of ocular surface squamous neoplasia. Ocular Surf, Elsevier Inc 2014;12:46-58.
61. Shousha MA, Karp C, Canto A, Ophthalmology $\mathrm{KH}-, 2013$ undefined. Diagnosis of ocular surface lesions using ultra-high-resolution optical coherence tomography. Elsevier. Available at: https://www.sciencedirect.com/science/article/ pii/S0161642012010445?casa_token=Rc157NFGxyEAAAAA:DU-v9pTAjgzge1 chqw4o58w7XQOiLJFjg1P3tf6OSNvMAWW8fTnhbKvQrd10mIn8WCNbNJpTuoc. Last access: 15 Feb 2021.

62. Kieval JZ, Karp CL, Shousha MA, et al. UItra-high resolution optical coherence tomography for differentiation of ocular surface squamous neoplasia and pterygia. Ophthalmol 2012;119(3):481-6. Available at: https:// pubmed.ncbi.nlm.nih.gov/22154538/. Last access: 17 Feb 2021.

63. Nanji AA, Sayyad FE, Galor A, Dubovy S, Karp CL. High-Resolution Optical Coherence Tomography as an Adjunctive Tool in the Diagnosis of Corneal and Conjunctival Pathology Ocular Surface. Elsevier Inc 2015:13; 226-35. Available at: https://pubmed.ncbi.nlm.nih. gov/26045235/. Last access: 17 Feb 2021.

64. Nanji AA, Sayyad FE, Karp CL. Topical chemotherapy for ocular surface squamous neoplasia. Curr Opin Ophthalmol 2013;24: 336-42. Available at: https://pubmed.ncbi.nlm.nih. gov/23680759/. Last access: 17 Feb 2021.

65. Poothullil AM, Colby KA. Topical Medical Therapies for Ocular Surface Tumors. Semin Ophthalmol 2006;21(3):161-9. Available at: http://www.tandfonline.com/doi/ full/10.1080/08820530500351694. Last access: 17 Feb 2021.

66. Chaugule S, ParkJ, Finger P. Topical chemotherapy for giant ocular surface squamous neoplasia of the conjunctiva and cornea: Is surgery necessary? Indian J Ophthalmol 2018;66(1):55. Available at: http://www.ijo.in/text.asp?2018/66/1/55/221799. Last access: 17 Feb 2021.

67. Venkateswaran N, Mercado C, Galor A, Karp $\mathrm{CL}$. Comparison of Topical 5-Fluorouracil and Interferon Alfa-2b as Primary Treatment Modalities for Ocular Surface Squamous Neoplasia. Am J Ophthalmol 2019;199:216-22. Available at: https://pubmed.ncbi.nlm.nih. gov/30471241/. Last access: 17 Feb 2021.

68. Viani GA, de Fendi LI. Adjuvant treatment or primary topical monotherapy for ocular sur- 
face squamous neoplasia: A systematic review. Arquivos Brasileiros de Oftalmologia. Conselho Brasileiro De Oftalmologia 2017;80:131-6. Available at: https://pubmed.ncbi.nlm.nih. gov/28591290/. Last access: 17 Feb 2021.

69. Sun Y, Hua R. Long-term efficacy and safety of subconjunctival/ perilesional 5-fluorouracil injections for ocular surface squamous neoplasia. Drug Des Devel Ther 2020;14:5659-65. Available at: https://pubmed.ncbi.nlm.nih. gov/33376309/. Last access: 17 Feb 2021.

70. Kusumesh R, Ambastha A, Sinha B, Kumar R. Topical Interferona-2basaSingleTherapyfor PrimaryOcular Surface Squamous Neoplasia. Asia-Pacific J Ophthalmol 2015;4(5):279-82. Available at: http://content. wkhealth.com/li nkback/openurl?sid=WKPTLP:landingpage\&an=01599573-201509000-00008. Last access: 17 Feb 2021.

71. Gupta A, Muecke J. Treatment of ocular surface squamous neoplasia with Mitomycin C. $\mathrm{Br} J$ Ophthalmol 2010;94(5):555-8. Available at: https://bjo.bmj.com/lookup/doi/10.1136/ bjo.2009.168294. Last access: 17 Feb 2021.

72. Chen C. Mitomycin C as an adjunct in the treatment of localised ocular surface squamous neoplasia. Br J Ophthalmol 2004;88(1):17-8. Available at: https://bjo.bmj.com/lookup/doi /10.1136/bjo.88.1.17. Last access: 17 Feb 2021.

73. Kurli M, Finger PT. Topical mitomycin chemo- therapy for conjunctival malignant melanoma and primary acquired melanosis with atypia: 12 years' experience. Graefe's Arch Clin Exp Ophthalmol 2005;243(11):1108-14. Available at: http://link.springer.com/10.1007/s00417004-1080-y. Last access: 17 Feb 2021.

74. Benage MJ, Morrow NC, Janson BJ, Greiner MA. Evaluation of interferon alpha $2 b$ as adjunctive therapy for conjunctival melanoma. Am J Ophthalmol Case Reports 2019;15. Available at: https://pubmed.ncbi.nlm.nih.gov/31193777/. Last access: 17 Feb 2021.

75. Kikuchi I, Kase S, Ishijima K, Ishida S. Longterm follow-up of conjunctival melanoma treated with topical interferon alpha- $2 b$ eye drops as adjunctive therapy following surgical resection. Graefe's Arch Clin Exp Ophthalmol 2017;255(11):2271-6.

76. Finger PT, Sedeek RW, Chin KJ. Topical Interferon Alfa in the Treatment of Conjunctival Melanoma and Primary Acquired Melanosis Complex. Am J Ophthalmol 2008;145(1):124-129.e1. Available at: https://linkinghub.elsevier.com/retrieve/pii/ S0002939407007726. Last access: 17 Feb 2021.

77. Stannard C, Sauerwein W, Maree G, Lecuona K. Radiotherapy for ocular tumours. Eye 2013;27(2):119-27. Available at: http://www. nature.com/articles/eye2012241. Last access: 17 Feb 2021. 